Arab World English Journal (AWEJ) Volume 12. Number3 September 2021

DOI: https://dx.doi.org/10.24093/awej/vol12no3.10

Pp. $144-158$

\title{
How Impoliteness Is Portrayed in a School Context: The Marva Collins as a Case Study
}

\author{
Mariam Fouad Kadhum \\ Department of English, College of Education for Women \\ University of Baghdad, Baghdad, Iraq \\ Corresponding Author: na688074@gmail.com \\ Nawal Fadhil Abbas \\ Department of English, College of Education for Women \\ University of Baghdad, Baghdad, Iraq
}

Received: 5/27/2021

Accepted: 7/8/2021

Published: 9/24/2021

\begin{abstract}
The present study attempts to examine verbal/nonverbal impoliteness in the classroom interaction and outside it in one of the movies, namely, The Marva Collins. Impoliteness, which is significantly studied within pragmatics, is a negative attitude towards particular behaviors. It always presumes to have emotional concerns for at least one participant who has caused it. This study is an attempt to examine verbal/nonverbal impoliteness in The Marva Collins movie. The study aims to investigate the different types of impoliteness strategies used in the four selected scenes and find out whether the speaker's status has anything to do with the types of impoliteness. Besides, the functions performed are also examined by following a qualitative method of research. To achieve the aim of the study, the researchers adopt Culpeper's model of impoliteness $(1996,2005)$. The study has concluded that positive impoliteness is the most dominant type of impoliteness, followed by withholding politeness. Moreover, the characters in The Marva Collins mostly employ affective impoliteness rather than the other functions of impoliteness. It is indicated to let the speaker imply the duty of the hearer to produce a negative emotional state. As a final point, Culpeper is the workable model used in analysing the data of this study.
\end{abstract}

Keywords: Culpeper's model of impoliteness, (im) politeness, negative impoliteness, positive impoliteness, pragmatics, The Marva Collins

Cite as: Kadhum, M. F., \& Abbas, N. F. (2021). How impoliteness is portrayed in a school context: The Marva Collins as a case study . Arab World English Journal, 12 (3) 144-158.

DOI: https://dx.doi.org/10.24093/awej/vol12no3.10 


\section{Introduction}

Phenomena of impoliteness occur not only in daily conversation but also in conversations found in different media such as films, books and TV drama. Sometimes, however, people intend to be impolite by saying or doing something wrong due to different reasons. First, they may be stimulated by a particular motivation, so they have the intention to damage others' faces (Bousfield, 2008). Second, sometimes being impolite is a reflection of one's psychological state, like feeling angry. Third, people may intend to be impolite for the sake of entertainment. Fourth, Culpeper (2011) declares that people sometimes intend to be impolite to get power via language. Mills (2005) presented how impoliteness is worthy in studying communication since it is a portion of it, as far as politeness, but from a distinctive viewpoint. In reality, some rules administer social communication and the insurance of interaction without breaking such rules; otherwise, there will be misbehavior or impoliteness. For this point, impoliteness could be separated from the hypothesized standards of a society of practice. This paper sheds light on the role of impoliteness in school interaction and its function in four selected scenes from The Marva Collins movie. It is intended to fill this gap by studying The Marva Collins movie pragmatically.

To convey a message from the speaker to the listener, it must be done unequivocally and straightforwardly. Some texts, however, are concealed behind the speaker's remarks for such purposes. The speaker does not say this directly so that the listener may draw inferences to the desired interpretation of the speaker. This phenomenon is studied in one of the branches of pragmatic linguistic studies.

From the point of view of Ninio and Snow (1996), pragmatics is introduced as the branch of linguistics that deals with language use, unlike syntax and semantics, which are concerned with the form and meaning of sentences, respectively. To Mey (2001), pragmatics is a shift from the paradigm of theoretical grammar, in particular syntax, to the paradigm of language use in human communication as determined by the conditions of society. According to Crystal (2008), pragmatics has been employed to study language according to the user's opinion in social interaction. Pragmatics, according to Levinson (1983, p.5), is the study of language usage. He says he analyzes language-context relations that are central to language comprehension. Agreeing with Birner (2013), pragmatics may be roughly defined as the study of language use in context as compared to semantics, which is the study of literal meaning independent of context. Horn and Ward (2006) view pragmatics as the study of those context-dependent aspects of meaning which are systematically abstracted away from the construction of content or logical form. To Yule (2010), pragmatics is the study of the implied meaning, or how we recognize what is hidden indeed on the off chance that it isn't said or written. In this manner, speakers (or writers) must be able to hang on to a lot of shared presumptions and desires when they interconnect. When arranging to get the messages that are expected to pass on, we must utilize the implications of the words, the context in which they happen and a few pre-existing information of what is expected to be carried out. Furthermore, pragmatics, as a field of study, comprises the study of some theories and models including the speech act theory, lexis, 
presupposition, conversational implicate and politeness. Concerning the latter, Culpeper (2005) argues that impoliteness is the very much parasite of politeness.

\section{Politeness}

Thomas (1995) defines 'Politeness' as "a genuine desire to be pleasant to others, or as the underlying motivation for an individual's linguistic behavior"(p.150), adding that there is no access to the addresser's motivation to be more or less polite than others, stating that there is access only to what addressers say and how their addressee(s) react.

Holmes (2001) observes that "being linguistically polite involves speaking to people appropriately in light of the relationship"(p.268), thus the level of 'politeness' to Holmes depends on the level of the social relationship between the interlocutors, which determines the level of formality used in the interlocution. Fairclough (1989) is in line with Holmes (ibid), stating that "politeness is based on the recognition of differences of power, degree of social distance" (p.66), proposing that the scale of 'Politeness' in any community depends on two factors: (1) An assessment of the social relationship between interlocutors (2) Knowledge of the social values and norms of the socio-cultural community involved. Furthermore, Abbas (2013) argues that politeness is one of the prevailing theories incorporated in the analysis of discourse, literary and non-literary; to bring what is called 'social harmony' that is regulated via several super and sub-strategies. Besides, Leech (1983, p.15) approved the notion of pragmatic strategy, since its main focus is on a goal-oriented discourse circumstance, in which the speaker uses language as arranged to deliver a real impact within the intellect of the hearer. In any case, and despite the truth that Leech's model is exceptionally much adjusted to linguistics that is implied by which certain objectives are accomplished, much of it is based on practical standards as communicative limitations, not on elaborating pragmatic methodologies, and typically more genuine aspects of his account of politeness. The concept of 'technique' is central to Brown and Levinson's (1987) demonstration of courteousness, fair conduct because it goes back to the early work on the lack of consideration (Culpeper, 1996).

\section{What is impoliteness?}

According to Limberg (2009), several research studies have been conducted in the field of politics (p.1377). However, not many researchers concentrate on the opposite of politeness, i.e., impoliteness, whereas impolite behavior is more attractive to society. For example, people will respond immediately by commenting or making an awkward gesture on their uncomfortable actions. Impoliteness is not as commonly studied as politeness, although certain areas of debate, such as political discourse, military speech, courtroom speech, police discourse and TV shows, and computer-mediated communication (CMC) have been investigated.

To Culpeper, Bousfield, and Wichman (2003), impoliteness is also considered as a complement to politeness field theory and also a revision of parts of it as well as it should not be 
considered as failed politeness since there is a clear relationship between them. Impoliteness has several synonyms in the English language and somehow, they all refer to the evaluation of negative behaviour.

Culpeper (2010) has studied the phenomenon of impoliteness extensively and says "Impoliteness is a negative attitude towards specific behaviour in specific contexts" (p.32). In his description of impoliteness, Culpeper found out a dilemma and later rewrote the definition of impoliteness. In a particular sense, the meaning of impoliteness has a negative attitude to such actions. It is supported by social perceptions and desires, including the meditation of a person or group's identity in other individuals' social interactions. Any behaviour, when incompatible with how a person is meant, how he/she wants to be, and/or how he/she feels it needs to be, can be regarded as apolitical. Such actions always have emotional effects or are supposed to do so. The impact is responsible or should be offensive (Culpeper 2011, p.23). Furthermore, Culpeper (2011) states that "sometimes it is not what is said that is impolite but how it is said"(p.57). This implies that prosody has its possess of impact on an expression; an expression, that would something else be legitimately respectful, can be made impolite by changing the intention (Culpeper, 2011). Leech, (2014) states "the best way to start theorizing about impoliteness is to build on a theory of politeness, which is a closely related phenomenon, in fact, the polar opposite of politeness" (p.219). While on the theory of impoliteness and emotional argument, Kienpointer (2008) states that impoliteness is "a prototype call for non-cooperative or competitive communicative behavior"(p.245).

\section{Verbal and nonverbal communication}

Verbal communication is single-channelled and moderately controlled, while nonverbal communication is multi-channeled and moderately genuine. Another distinction, concurring to Andersen (1999) is that verbal communication could be a socially based framework, while most of the nonverbal communication may be a naturally based framework. He outlines that a few nonverbal incidents, such as certain signals and part of touching, are not the same thing in each country, as it is culture-specific (as cited in Huang 2007, pp.115-117). The indirect speech act is perhaps the most critical pragmatic principle of the current study on impoliteness since it is commonly connected with the concept of politeness. The more indirect the act of speech, the more courteous it is. We may, for example, use the direct version 'shut up' if we want some people to be quiet, or the indirect version 'Would you please stay silent for a while?'

The indirect version is a rather courteous way to ask for silence, while most people view the direct version as very unpleasant. The degree of politeness, however, is linked to factors such as influence, cultural customs and participants' closeness, which is why the less polite version is often used. Some parents will claim, for instance, that their children are shut, but possibly they will not tell their colleagues (Huang 2007). 
Although the language spoken is a major component of our daily communication, many researchers in the field believe that nonverbal communication is at least as vital as verbal communication. In addition, Anderson (1999) refers to the message as "direct, non-arbitrary, intrinsic to what they represent" (p.3). This is because just about one-third of the contact between humans is verbal. It should be borne in mind here that nonverbal communication is not a language, but can have similar functions. There is nonverbal communication besides words, and nonverbal and verbal communication typically occurs simultaneously (Andersen, 1999). In expansion to age, both sex and culture also influence nonverbal communication. Here, to Hall (2006), men are considered to be louder, grin and look less precise to their feelings than women.

\section{Strategies of impoliteness}

Concerning the political policies proposed by Brown and Levinson (1987), Culpeper (1996) creates a basis for impoliteness. With one review developed in (2005), he suggested a fivepronged strategy model.

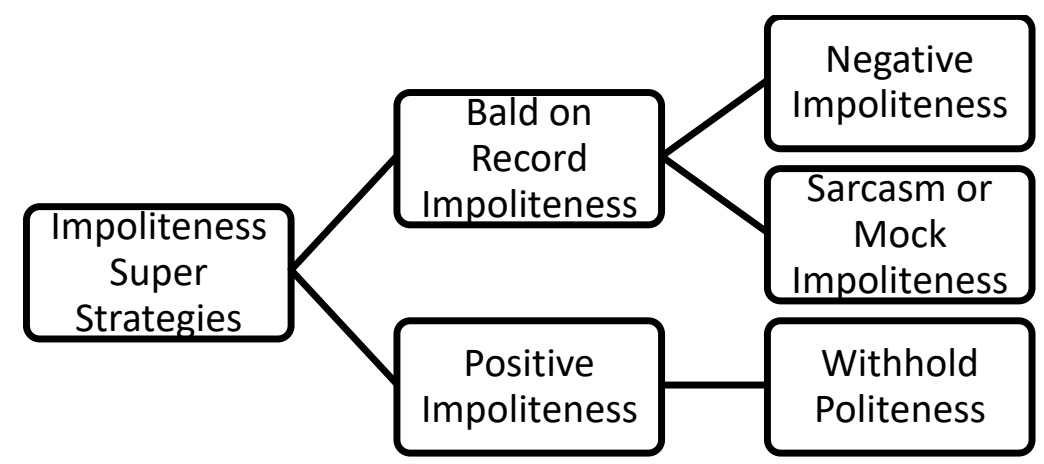

Figure 1. Impoliteness super strategies proposed by Culpeper (1996, p.8).

Culpeper (1996, as cited in Abbas, 2012) defines the concept of impoliteness as the use of five strategies to attack the hearer's face. The following are the five strategies in brief:

\subsection{Bald on record impoliteness}

Culpeper (2005, p.41) states that the speaker in this strategy directly, clearly, unambiguously, and concisely implements the Face Threatening Act (FTA). It is done when the face is not trivial or minimized. It is carried out when the speaker intends to target the addressing to the person's face. Very quickly, the most evident and straightforward impoliteness is reported impoliteness. This kind of impoliteness is popular among people with close ties, according to Culpeper (1996). Wieczorek (2013, as cited in Muhammed \& Abbas 2016) explains the distinction between the bald on record politeness of Brown and Levinson and the bald on record impoliteness of Culpeper. Here, the expression is incredibly effective concerning the conversational adages of Grice. Agreeing with Brown and Levinson, the researchers do not take after these adages in discussions, but speakers are incited by them to pay consideration to the confront needs to avoid any struggle (Brown \& Levinson, 1987). The previous is connected to specific circumstances 
where the hazard to confront is negligible without any consideration to assault the hearer confront. In general, this strategy is easy when the speaker (S) fails to listen to/hear $(\mathrm{H})$ and does not consider the act relevant. For example:

Dean: You are nuts. You are nuttier than a fruit cake Alves.

Sam: What? What did you say?

Here, the Dean's utterance is an FTA. He does impoliteness to Sam without any ambiguity.

\subsection{Positive impoliteness}

This strategy is designed to attack the optimistic face of the addressee, which needs to be acknowledged by others, according to Culpeper (2005, p.40). Some of the production methods can be used for this strategy:

- Ignoring, snubbing the other failure to recognize the involvement of the others.

-Remove the other from a job.

-Dismiss from, for example, denying affiliation or shared ground with others, preventing sitting.

-Be disinterested, carefree and unfriendly.

-Using improper identification markers - use titles and nicknames, for example, if a close relation or a nickname is related to a distant connection.

-Use a dark or hidden language-for instance, use jargon to mystify another or use a community code known to some, but not the goal.

-Seek discrepancy- choose a delicate topic.

-For example, do not avoid quiet, laugh, or use small conversations, making others uncomfortable.

-Use taboo terms - swear, violent, or secular.

-Demand other names - use negative appointments.

\subsection{Negative impoliteness}

This strategy is defined by Culpeper (2005, p.41) as the strategy the addressee wants to strike. This approach is used by the speaker to damage the recipient's freedom of action. According to Culpeper (2005, p. 41), negative impoliteness includes "the use of strategies developed to damage the recipient's negative face wants". Additionally, he accepts that this technique covers "the association rights to some extent". The output strategies of negative impoliteness strategies as the following:

-Invade the other's space, frighten, instill a belief that action detrimental to the other will occur. -Condescend, scorn or ridicule - emphasize your relative power.

-Be contemptuous; do not treat the other seriously.

-Belittle the other.

-Explicitly associate the other with a negative aspect - personalize.

-Use the pronouns 'I' and 'you', and put the other's indebtedness on record etc.

\subsection{Sarcasm or mock impoliteness}

It means an act of face-threats using mockery or illusionary politics. According to Culpeper (1996), impoliteness is also considered as insincere politeness between S and $\mathrm{H}$. He wrote about 
impoliteness in a military formation camp, in his article Towards an Anatomy of Impoliteness and he provided the following example:

Speaker 1: Hey, you know something about you?

Speaker 2: What about?

Speaker 1: With your little acting girl, you impress people.

The word 'impress' is frequently used to convey a pleasing judgment, but speaker ' 1 ' says that to make fun of speaker 2. The utterance is thus insincere and it is referred to as 'mock politeness'.

Culpeper (2005, p. 49) has explained this strategy in the following example: -I once turned up late for a party and upon explaining to the host that I had mistaken 17:00 hours 7 o'clock, I was greeted with a smile and the words 'you silly bugger' I knew that the impoliteness was superficial, it was not real and that I had been accepted into the party.

\subsection{Withhold politeness}

Culpeper (1996, p. 357) points out that impoliteness is accomplished through the nonappearance of politeness work where it would be anticipated. For occurrence, falling flat to thank someone for a blessing may be taken as a considerable lack of consideration (Curlpaper, 2006, p. 42). In this procedure, the speaker does not do the polite act where the listener would anticipate one. Being calm is additionally withhold politeness. Withhold politeness happens when the speaker does not do the politeness wished by the hearer, or just keeps silent, for instance:

Wife: Honey, come here!

Husband: Okay, wait a minute.

Wife: Happy birthday, Honey! This is a little gift for you.

Husband: (keeps silent)

The husband fails to thank his wife for the present given to him. Thus, it can be called 'withhold politeness' (Culpeper 1996).

This type of impoliteness occurs because there is a lack of politics right now, which should be demonstrated (Culpeper 2005). Failure to thank someone or express appreciation for a favour can be regarded as intentional impoliteness, as seen in the following example.

(The example shows an arbitrator using the extract from The Clamper, who recently declined an appeal by a car owner against a car park.)

Arbitrator: Well, thanks a lot for the arrival.

Owner of car: I thank you not. (Culpeper et al., 2003, p.1559)

In expressly rejecting politeness, the car owner does not give thanks to the arbitrator. 


\section{Functions of impoliteness}

There were not many attempts to define impoliteness functions. Culpeper (2011) has suggested the latest effort to achieve three functions of impoliteness: affective impoliteness, Coercive Impoliteness, and Entertaining Impoliteness.

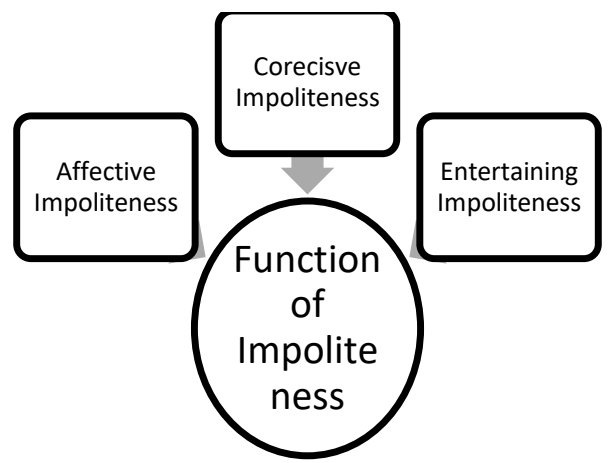

Figure 2: Functions of impoliteness as proposed by Culpeper (2011).

Culpeper (2011) proposes three functions of impoliteness in his up-to-date book, Impoliteness: Using Language to Cause Offense (as cited in Muhammed \& Abbas, 2016). These sorts share the work of negating interpersonal connections, personalities, and social standards. Each one is shown below.

\subsection{Affective impoliteness}

The first function of impoliteness is treated as emotional impoliteness. This role includes an emotional explosion during a conversation between the speaker and the hearer. Culpeper (2011, P. 223) claims that affective impoliteness shows an excessively heightened feeling, such as indignation, which implies the duty of the goal to produce a negative emotional state.

The example below shows the impoliteness of a girl who is angry toward the boy.

Girl: How dare you go too far on me! That's not the way you should handle me! Who the fuck are you thinking?

Boy: I have to go. I've got to do some things.

In the example, the girl uses impolite utterances to show her anger and frustration toward the boy.

An example of this can be found in the following:

- You have insulted me for the last time.

This utterance conventionalizes impoliteness insults, and this is clarified with a negative value. Here, the speaker reveals his anger towards the hearer and this leads to producing a negative emotional atmosphere between the speaker and the hearer (Haung, 2014, p. 150). For instance, in making someone crazy, the addressee expresses his annoyance by using impolite utterances to tell the addresser that he is unwanted anymore. 


\subsection{Coercive impoliteness}

The second impoliteness function is that of coercive. It is uncomfortable to rearrange values between the supplier and the aim in which the manufacturer gains more or is strengthened or covered by their existing advantages (Culpeper 2011, p.226). The terms producer and objective here may not only be used for individuals but also groups or organizations.

This role seems to arise in circumstances where there is a different social systemic force or social condition, according to Culpeper (2011, p. 252). Nevertheless, the accumulation of social influence can also be used in a more egalitarian way.

In the following conversation between a manager and her assistant, an example of manipulative impoliteness can be seen.

Manager: I want to bring my cup of coffee from the coffee shop across the street for my presentation on my desk tomorrow in 10 minutes.

Secretary: Mistake... All right, but right now I have my lunch. Is it all right if I do it after I've done it?

Manager: What you're doing, I don't care. Ten minutes. Ten minutes.

The manager's impoliteness is to confirm his position as a boss in this example. Just as she has a more important position than her office assistant, she pressures her secretary to take her orders by using her power.

\subsection{Entertaining impoliteness}

The ultimate role of impoliteness is entertaining. The purpose or the possible objective of impoliteness, including entertainment, is to manipulate this role of impoliteness (Culpeper 2011, p. 252). A victim or a possible victim is often necessary for combination with all genuine impoliteness. Here, in entertaining impoliteness, the addressee amuses of the hearer and enjoys the feeling of obtaining amusement.

It's unforeseen that even though it appears to hurt or anger people, it can be fun. Unlike other pragmatic experiments with a dyad of speakers and audiences, impoliteness can be organized similarly for both the listening crowd and the target audience (Culpeper 2011, p.234).

The example below shows the amusing impoliteness. Girl A ridiculed the dress of Girl B in a crowd:

Girl A: What a beautiful dress you're wearing tonight.

Girl B: Well, thank you. Thank you. I made it myself. I made it myself.

Girl A: Wow, wow, right? For I want one for my cat. I want one...

On the whole, the three types share the function of contradicting interpersonal relationships, identities, and social norms (Mohammed \& Abbas, 2015). 


\section{Methodology}

To achieve the aims of the study, the researchers adopt a qualitative method. Having a qualitative analysis enables the researchers to expand the scope of their analysis to examine the examples with more depth. According to Merriam (2009), qualitative research regards the researcher as the main instrument who collects and analyses the data of the study.

The present study focuses on the application of Culpeper's (2005) impoliteness strategies. In The Marva Collins, the researchers selected four scenes to analyse the participants' impoliteness utterances in different ways. The first scene is between Mrs. Collins and the two of her students Roxanne and Martin. While the second scene is about Mrs. Collins and one of her students, his name is Martin. The third scene is about a talk between Mrs. Collins and Martin. While Mrs.Collins is explaining the material, Martin does not pay attention to her and he is busy bothering Roxanne who is one of the students in the class. The fourth scene is between $\mathrm{Mr}$. Duffy and Mrs. Collins. The conversation is about some duties that teachers have to do this week.

To carry out the study, there are certain procedures to follow to do the analysis: watching the movie more than one time, applying the proposed model by identifying the super and substrategies of impoliteness, examining the identified strategy and showing the context in which it occurs. It should be highly remembered that the nonverbal interaction is not a dialect, despite that its capacities can be comparable. Nonverbal interaction happens close to language, and nonverbal and verbal communications, as a rule, exist at the same time. Most of the lack of consideration includes moreover nonverbal components, such as diverse expressions of the face and tones of voices. A few occasions of the lack of consideration are made through the nonverbal interaction.

\section{Analysis and discussion}

In The Marva Collins movie, the researchers analyze the different ways participants employ impoliteness utterances. The researchers selected four extracts from two different categories, namely, student and teacher and teacher and principal. These selected scenes which all reflect the speaker's and the hearer's face-attacks are shown in the following extracts.

\section{Extract 1: Student and teacher}

Mrs. Collins opens her school inside her house. The participants are Mrs. Collins and two of her students, namely, Roxanne and Martin.

Mrs. Collins: You will read a difficult book twice a month. You'll memorize a poem every week. And you'll write a theme every single day. There'll be mathematics, vocabulary...history... Roxanne: Say what? I am not doing all that junk. (She feels bored and angry)

Martin: I don't gotta learn anything. (He shouts with angry facial expressions) 
Mrs. Collins starts her first-day teaching students who suffer from different problems in their life. She begins introducing herself to those kids and talking about the rules they have to follow. While she is talking, Roxanne interrupts her, describing teaching as being junk. Roxanne's utterance of the taboo word junk is the sub-strategy of positive impoliteness which attacks the addressees positive confronts needs. The function here is that of affective impoliteness which is used by Roxanne in situations when she expresses her bad feelings to show the negative emotional state, such as frustration. Meanwhile, Martin is a student who is always in trouble with his teacher as well as his colleagues. Martin lives in a poor family; he suffers from certain issues which affect his personality. Martin disrespects his teacher and he becomes angry at her. Martin misbehaves and keeps playing with his ruler without giving any attention to his teacher. This is a positive impoliteness strategy when his reaction reflects the "unconcern, disinterest, and insensitive" about learning in general and his teacher in particular. It is effective impoliteness when Martin uses quite an inconsiderate expression to express that he is no longer to communicate with the teacher's latent impact on him and to inform her that he is no longer unwanted. It is effective impoliteness, when the students express their anger towards their teacher and this, thus, produces a negative passionate climate in the class.

\section{Extract 2: Student and teacher}

This scene takes place in the class. Mrs. Collins tries to drive Martin's attention to the lesson, but he no more cares about what she says.

Martin: [TAPPING]

Mrs. Collins: If you do not wish to learn, you have the right to fail. Now listen...I love you. I love you. You're a bright boy. You're a handsome boy. But you do not have the right to disturb the other children's right to learn. Now if you wish to fail, you may do so quietly. Stop interrupting. And stop tapping that pencil. [PENCIL DROPS] Pick it up. [SIREN WAILING IN DISTANCE] Pick it up.

Martin :( gazes at Mrs... Collins: with angry expressions). Mrs. Collins: Thank you.

Martin: (keeps silent).

Martin misbehaves with his teacher and his friends and the only thing he likes to do is to fight with others. While Mrs. Collins is talking about success, Martin interrupts her by tapping on the desk. She tells him to stop doing that twice, but he raises his eyes brow with anger which is considered one of the non-verbal communications to express feelings. This is not the only time the teacher repeats herself. She also repeats herself when she asks Martin to pick up the pencil. Here repetition can be considered a good contribution to the interpretation of the utterance (Abbas \& Abdul Zahra 2007). It tells that the teacher is fed up with Martin. Martin's reaction of keeping silent, on the other hand, can be analyzed as withhold politeness by not responding to his teacher. This is affective impoliteness when Martin communicates his outrage towards his teacher and this subsequently produces a negative enthusiastic climate in the class. Martin does 
not behave respectfully in this approach where Mrs. Collins would anticipate one. Being quiet is likewise withholding politeness.

\section{Extract 3: Students and teacher}

This extract includes a talk between Mrs... Collins and one of her students, Martin. Mrs. Collins: Martin will never have thoughts of his own...because he's too busy to think. So when the man comes and offers him twol0s for a $\$ 50$ bill, he'll never know... whether he has a good deal or not.

Martin: I know that. He'd have to give me five 10s for \$50. I'm no dummy.

Mrs. Collins: Then maybe you know that the good Lord gave us two ears and one mouth...so we could listen twice as much as we talk.

[STUDENTS LAUGH]

Martin: I can listen and talk at the same time because I am as fine as a shiny new dime. Mrs... Collins: Beautiful, Martin. Beautiful. Now for tomorrow, I want you to look up the etymology of the word "dime."

Mrs... Collins: Where and when it was minted. How much silver went into it? That's your homework for tomorrow. Because I'm gonna get more than a shiny new dime's worth of learning out of you.

Mrs. Collins is explaining the subject, but Martin does not pay attention to her and he is busy bothering his friend Roxanne. When Mrs. Collins notices that, she tries to drive his attention by saying that if a man comes to him and gives him some money twolos for a $\$ 50$ bill, he'll never know... whether he has a good deal or not. Here, Martin loses his temper and he replies in a sharp tone which reflects his anger by uttering the "taboo word" dummy. Martin' utterance is a sub-strategy of positive impoliteness through saying a "taboo word" to his teacher's face. The effective function of Culpeper's impoliteness appears in this scene. This function is represented by the impolite item I can listen and talk at the same time because I am as fine as a shiny new dime produced by Martin. His expression exposes his feelings of anger towards Mrs. Collins.

\section{Extract 4: Teacher and principal}

This scene is taken place in Mr. Duffy's office. The participants in this extract are Mr. Duffy and Mrs. Collins.

Mr. Duffy: The agenda, the agenda. Thank you. The next item, the boys' bathroom in the south hall, okay? From now on during regular class time, the boys' bathroom will be locked. Don't even bother to issue hall passes in this hallway.

Mrs. Collins: I still happen to have this false alarm on my floor that keeps going off, Mr. Duffy. Mr. Duffy: Mrs. Collins, don't you have anything better to do than worry about that damn fire bell?

MALE TEACHER: Really? 
Mrs. Collins: Yes, I do. Teaching. But between irrelevant zoo trips and false alarms, we are losing the battle. You are robbing us of class time, Mr. Duffy. Why don't you send your agenda on a field trip and let us teach?

The conversation is about some duties that teachers have to do this week such as filling the reports during the classes, taking the students for a trip, closing the boys' bathroom and the other issues, but without discussing the students' evaluation in the subjects. Mrs. Collins gets bothered by the false alarm that no one talks about. Mrs. Collins cares more about teaching rather than other things. Meanwhile, Mr. Duffy loses his temper by puts his shoes on the chair and he utters an impolite word in a high tone with angry facial expressions towards Mrs. Collins by saying 'damn'. Here, Mr. Duffy's behavior is disrespectful to Mrs. Collins. The use of the taboo word 'damn' is one of the sub-strategies of positive impoliteness. The function is that of affective when Mrs. Duffy expresses a kind of frustration at Mrs. Collins. This produces a hostile interpersonal climate between the two.

\section{Conclusion}

The concept of impoliteness is realized in an unexpected way depending on the setting of the circumstance. It can be analyzed from the speaker's and the hearer's viewpoint since it depends on the speaker's deliberate conduct and the hearer's gathering of interpretation. Culpeper's model (2005) has been outlined to show how the procedures of the lack of consideration methodologies are controlled by the characters within the two chosen different levels, namely, (student and teacher) and (teacher and principal).

There are five impoliteness strategies used by Culpeper $(1996,2005)$ they are: bald on record impoliteness, positive impoliteness, negative impoliteness, sarcasm or mock impoliteness, and withhold politeness. According to Culpeper's model (2005), there are three functions of impoliteness: affective, coercive, and entertaining. Each of the impoliteness strategies has its realizations. In the first example, when Roxaane uses the "taboo word" junk toward her teacher. She expresses her bad feeling to show a negative emotional state, such as frustration. Besides, Martin disrespects his teacher and he becomes angry at her. Martin misbehaves and keeps playing with his ruler without giving any attention to his teacher. This is a positive impoliteness strategy when Martin's reaction reflects the "unconcern, disinterest, and insensitive" about learning and his teacher. In the second example, when Mrs. Collins talks about success; Martin interrupts her by tapping on the deck. She tells him to stop doing that, but he raises his eyes brows with anger which is considered one of the non-verbal communications to express feelings. Martin's reaction is considered to withhold politeness for keeping silent without responding to his teacher. In the third example, Martin loses his temper toward his teacher and replies in a sharp tone expressing his anger by uttering the taboo word 'dummy'. In the fourth example, the topic of conversation is about Mr. Duffy and Mrs. Collins. When loses his temper by putting his shoes on the chair, Mr. Duffy utters an impolite word in a high tone with angry facial expressions towards Mrs. Collins by saying 'damn'. Here, Mr. Duffy's behavior is disrespectful 
to Mrs. Collins. The use of procedures planned to attack the addressees positive confront needs and the capacities of both techniques are those of the affective impoliteness. The researchers show how this movie reveals the status of the teacher. Besides, positive impoliteness is the most prominent among the other type of impoliteness through which the affective function is revealed. This finding agrees with that of Kadhum and Abbas (2020) in their study about the role of impoliteness in You Tube.

\section{About the Authors:}

Mariam Fouad Kadhim is an M.A. student in the Department of English, College of Education for Women in the University of Baghdad. Her major is Linguistics and she has interests in several fields within Linguistics including Applied Linguistics.

ORCID ID: https://orcid.org/0000-0003-0376-7680

Nawal Fadhil Abbas got her PhD in English Language and Linguistics in 2014 from the school of Humanities, University of Sains Malaysia. Now she is an assistant professor teaching at the College of Education for Women, University of Baghdad. Her field of study is Semantics and Pragmatics. Other fields of interest include Critical Discourse Analysis, Critical Stylistics and Corpus Linguistics. https://orcid.org/0000-0003-2608-6909

\section{References}

Abbas, N. F. \& Abdul-Zahraa, S. (2007). Repetition in Wollstonecraft's Letters. Journal of Humanities, 3(10), 544-563.

Abbas, N. F. (2012). Linguistic Impoliteness and Social Disruption in Literary Discourse. International Journal of English and Education, 1(2), 180-191.

Abbas, N. F. (2013). Positive Politeness \& Social Harmony in Literary Discourse. International Journal of Applied Linguistics \& English Literature, 2(3), 186-195.

Andersen, P. A. (1999). Nonverbal Communication. Forms and Functions. London, Toronto: Mayfield publishing company.

Birner, B. (2013). Introduction to Pragmatics. British: Blackwell.

Bousfield, D. (2008). Impoliteness in interaction. Amsterdam: John Benjamins Publishing Company.

Culpeper, J. (1996). Towards an anatomy of impoliteness. Journal of Pragmatics, 25(3), 349367.

Culpeper, J. (2005). Impoliteness and entertainment in the television quiz show: The Weakest Link. Journal of Politeness Research, 1, 35-72.

Culpeper, J. (2010). Conventionalized impoliteness formulae. Journal of Pragmatics, 42, 32323245.

Culpeper, J. (2011). Impoliteness: Using language to offend. Cambridge: Cambridge University Press.

Culpeper, J., Bousfield, D. \& Wichmann, A. (2003). Impoliteness: With special reference to dynamic and prosodic aspects. Journal of Pragmatics, 35(10), 1545-1579.

Crystal, D. (2008). A Dictionary of Linguistics and Phonetics (6th ed.). Oxford: Blackwell. 
Fairclough, N. (1989). Language and Power. London: Longman.

Holmes, J. (2001) An Introduction to Sociolinguistics. Edinburgh: Longman.

Hall, J. (2006). Women's and Men's Nonverbal Communication. Oxford: Oxford University Press.

Horn, L. \& Ward, G. (2006). The Handbook of Pragmatics. Oxford: Blackwell.

Huang, Y. (2007). Pragmatics. Oxford: Oxford University Press

Kadhum, M. \& Abbas, N. (2020). Impoliteness in Relation to You Tube: A Pragmatic Study. Journal of the College of Basic Education, Special Issue, 105-123.

Levinson, L. C. (1983). Pragmatics. New York: Cambridge University Press.

Limberg, H. (2009). Impoliteness and threat responses. Journal of Pragmatics. 41, 1376-1394.

Mey, J. (2001). An introduction (2 ed.). Oxford: Blackwell.

Muhammed, H. N. \& Abbas, N. (2015). Pragmatics of Impoliteness and Rudeness. American International Journal of Social Science, 4(6), 195-205.

Muhammed, H. N. \& Abbas, N. (2016). Impoliteness in Literary Discourse: A Pragmatic Study. International Journal of Applied Linguistics \& English Literature, 5(2), 76-82.

Ninio, A., \& Snow, C. (1996). Pragmatic development. Oxford: Wes View Press.

Thomas, J. (1995). Meaning in Interaction: An Introduction to Pragmatics. New York: Longman. 